\title{
Profile of Double of Undernutrition Problem, Coexistence with Anemia among Pregnant Women Indonesia 2018: A Cross Sectional Survey
}

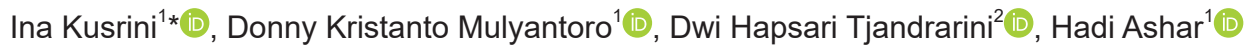 \\ ${ }^{1}$ Health and Research Development Unit Magelang, National Institute Health Research and Development, Ministry of Health \\ Indonesia, Jakarta, Indonesia; ${ }^{2}$ Health and Research Development, Center of Public Health, National Institute Health Research \\ and Development, Ministry of Health Indonesia, Jakarta, Indonesia
}

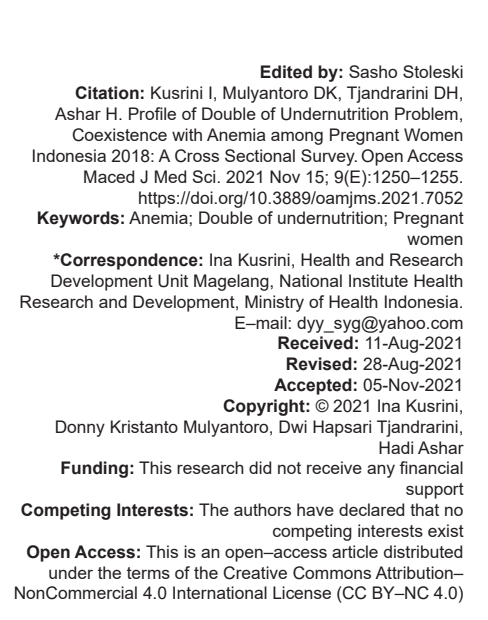

Introduction

Anemia is still a major cause of pregnancy malnutrition worldwide, and it is a major public health concern [1]. In 2019, the global prevalence of anemia in pregnant women was $36.5 \%$. Southeast Asia had the highest prevalence of anemia in pregnant women, with nearly $48 \%$, followed by Africa with $45.8 \%$ and the Eastern Mediterranean with $36.5 \%$ [2]. In pregnancy, anemia has an impact on pregnancy outcomes. The longitudinal studies showed an association of anemia during pregnancy to low birth weight in her baby [3]. Malnutrition also can impair growth and lead to several congenital abnormalities [4]. Inadequate micronutrients can interfere with the growth, production, and vital organs optimum duties.

As well as pregnancy is a critical period in the first 1000 days of human life [5], [6]. Balanced nutritional intake of both macronutrients and micronutrients is important to meet pregnancy increased requirements [7], [8]. In the meantime, undernutrition during pregnancy will adversely affect the mother and fetus [9]. A previous research reported low birth weight, preterm birth, infant mortality, and morbidity are increased as a risk of malnutrition during pregnancy [4], [10]. Another study reveals malnutrition in the first 1000 days of life may disturb growth, development, and potential health concerns in adult growth such as obesity and metabolic disorders [11], [12]. A report in Africa showed the effect on mothers where $23.5 \%$ of malnourished pregnant women are at risk of pregnancy complications [13], [14]. Another study found an adverse effect on the mother [14] and the fetus born in growth and development [4], [15].

The prevalence of malnutrition during pregnancy is demonstrated globally in developed countries, including anemia, stunted, and chronic energy malnutrition. Anemia is the common type of pregnancy malnutrition. Anemia was predicted as a determinant factor of maternal mortality rate in pregnant women due to abnormal delivery bleeding or postpartum hemorrhage. In Indonesia, anemia among pregnant women increases to $48.9 \%$ in 2018 from 
$37.1 \%$ in 2013. Another issue of malnutrition was the prevalence of CEM, which in 2013 amounted to $24.2 \%$ and $17.3 \%$ in 2018 . Stunted in pregnant women was reported $31,3 \%$ in 2013 and $30.5 \%$ in 2018 , based on the Basic Health Research Survey [16], [17].

Along with a change in the epidemiological trend, malnutrition can establish dietary issues simultaneously [18]. The double burden indicates that overnutrition has increased while undernutrition remains [19]. These can occur at the individual, family, and population levels [20]. Otherwise, double of undernutrition macronutrient and micronutrient deficiencies also was shown. Anemia was a major malnutrition issue in pregnant women, and it may be more severe if it occurs in combined with another undernutrition problem [10]. This study aims to describe the double undernutrition in pregnant women with anemia and investigate the correlation between another undernutrition and anemia. It was necessary to describe the entire nutritional problem in pregnant women, which could result in a double burden of malnutrition during the pregnancy period.

\section{Methods}

\section{Study design}

This study uses secondary data from the Indonesia Ministry of Health's Basic Health National Survey (Riskesdas) in 2018. Thenational cross-sectional study used a multi-stage cluster sampling method. It divided it into two categories: A sample for public health indicators and biomedical indicators. It collected overall risk blood samples from 2.500 census blocks chosen as a systemically selected cluster for each district/ city, including rural and urban areas. The Probablity Proportional Size (PPS) technique uses a block census, with the number of households revised from the 2010 population census. The next step is to pick ten census buildings as a household sample systematically. In 26 provinces, sub-samples are rendered to define the national level [17].

\section{Inclusion and exclusion criteria}

Women who were pregnant at the time the basic health research survey was conducted were eligible for inclusion. The exclusion criteria were pregnant women who lacked data on anthropometric measurements and hemoglobin tests for anemia.

\section{Sample}

Based on the Lemeshow method [21], a minimum sample size of $95 \%$ Confidence Interval
(CI) is required for this study with absolute precision: Anemia $48.9 \%$, the minimum sample sizes are 381 ; CEM with $17.1 \%$, the minimum sample size is 222 . We used the highest number calculation, 381, for the minimum sample size for this study. Considering the effect design and dropout anticipation due to minimum criteria, we add 150 samples for backup. The number of samples used for the study was 484; consider inclusion and exclusion criteria for the appropriate sample sizes.

\section{Variables}

The anthropometric scale was determined by maternal body height instrument and middle upper arm circumference (MUAC). The maternal body height instrument was used to determine the anthropometric scale, which had a precision of $0.1 \mathrm{~cm}$. If a pregnant woman's height was $<150.1 \mathrm{~cm}$, she was considered stunted. If the MUAC is $<23.5 \mathrm{~cm}$, this indicates chronic energy malnutrition. A rapid test kit for anemia is used to diagnose anemia using hemoglobin (the cyanmethemoglobin). According to the World Health Organization (WHO) guidelines, anemia was defined as a hemoglobin level of $11.0 \mathrm{~g} / \mathrm{dl}$. Maternal education level was classified into three categories, low (length of education lower than 9.1 years), middle (length of education between 9.1 until 12 years), and high (length of education more than 12 years).

\section{Statistically method}

The profile of double undernutrition in pregnant women has been described using univariate data analysis in complex samples, considering the weight for anemia sample in pregnant women. Rural and urban living areas were used for stratification. Then, multivariate analysis with logistic regression was used to investigate the risk of another nutrition problem associated with anemia in rural and urban areas. The licensed SPSS version 21 was used for data analysis.

\section{Ethical number}

The study was approved by the National Institute of Health Research and Development, Indonesia, Ministry of Health Ethical Committee with the number of ethics LB.02.01/2/KE.024/2018. All participants were agreed and assign informed consent.

\section{Results}

The number of sub-samples from the 2018 Riskesdas survey was 484, with 239 in rural areas and 245 in urban areas. The findings of the descriptive 
study suggest that the average age of the mother was around $27 \pm 6$ years at the last pregnancy and that the mother's age was about $21 \pm 4$ years at the first pregnancy.

Macronutrient deficiencies can be predicted by Body Mass Index (BMI), which evaluates nutrient status in adults and middle-upper arm circumference (MUAC) for pregnant women [22], [23]. BMI cannot be used due to physiological changes in pregnancy, such as increasing body weight. Another indicator for evaluating nutritional status in pregnant women is maternal weight gain and maternal weight for gestational age, as this study cannot provide. The middle arm circumference below $23.5 \mathrm{~cm}$ in women with pregnancy indicates malnutrition due to lower energy and protein by forecasting sub-cutaneous fat and muscle volumes [22] that was classified as CEM.

Table 1 shows pregnant women's nutritional status based on rural and urban features. The data show that anemia is the most common among pregnant women with the lowest education, work in household categories and young mothers under the age of 20 years. Stunted has been shown to be more prevalent in low-school pregnant women, household and maternal workers and in pregnant women who has $>35$ years of age. CEM was demonstrated in women with the lowest levels of education, work and maternal age $<20$ years.

Table 1: Proportion of pregnant women characteristics and nutrition status in rural and urban area

\begin{tabular}{|c|c|c|c|}
\hline \multirow[t]{3}{*}{ Demographic Characteristics } & \multicolumn{3}{|c|}{ Type of residence } \\
\hline & Rural & Urban & Both \\
\hline & $\%$ & $\%$ & $\%$ \\
\hline \multicolumn{4}{|l|}{ Anemia } \\
\hline \multicolumn{4}{|l|}{ Mother education } \\
\hline High & 42.9 & 23.1 & 30.0 \\
\hline Middle & 38.3 & 31.5 & 34.6 \\
\hline Low & 38.0 & 41.2 & 39.2 \\
\hline \multicolumn{4}{|l|}{ Household occupation } \\
\hline No work & 33.3 & 31.9 & 32.7 \\
\hline Work & 41.1 & 32.9 & 36.9 \\
\hline \multicolumn{4}{|l|}{ Maternal age } \\
\hline$<20$ years & 53.8 & 40.0 & 46.4 \\
\hline $20-35$ years & 36.5 & 32.3 & 34.4 \\
\hline$>35$ years & 43.2 & 31.7 & 37.2 \\
\hline \multicolumn{4}{|l|}{ Stunted } \\
\hline \multicolumn{4}{|l|}{ Mother education } \\
\hline High & 42.9 & 19.2 & 27.5 \\
\hline Middle & 43.6 & 23.8 & 32.6 \\
\hline Low & 44.6 & 37.3 & 42.0 \\
\hline \multicolumn{4}{|l|}{ Household occupation } \\
\hline No work & 39.5 & 27.8 & 34.0 \\
\hline Work & 46.2 & 25.4 & 35.3 \\
\hline \multicolumn{4}{|l|}{ Maternal age } \\
\hline$<20$ years & 23.1 & 26.7 & 25.0 \\
\hline $20-35$ years & 46.6 & 24.3 & 35.4 \\
\hline$>35$ years & 37.8 & 34.1 & 35.9 \\
\hline \multicolumn{4}{|c|}{ Chronic energy malnutrition (CEM) } \\
\hline \multicolumn{4}{|c|}{ Mother education } \\
\hline High & 7.1 & 15.4 & 12.5 \\
\hline Middle & 18.8 & 14.9 & 16.6 \\
\hline Low & 19.6 & 15.7 & 18.2 \\
\hline \multicolumn{4}{|l|}{ Household occupation } \\
\hline No work & 13.6 & 15.3 & 14.4 \\
\hline Work & 20.9 & 15.0 & 17.8 \\
\hline \multicolumn{4}{|l|}{ Maternal age } \\
\hline$<20$ years & 30.8 & 53.3 & 42.9 \\
\hline $20-35$ years & 18.5 & 13.8 & 16.1 \\
\hline$>35$ years & 13.5 & 7.3 & 10.3 \\
\hline
\end{tabular}

This research shows the profile of pregnancy malnutrition. Figure 1 shows the overall major

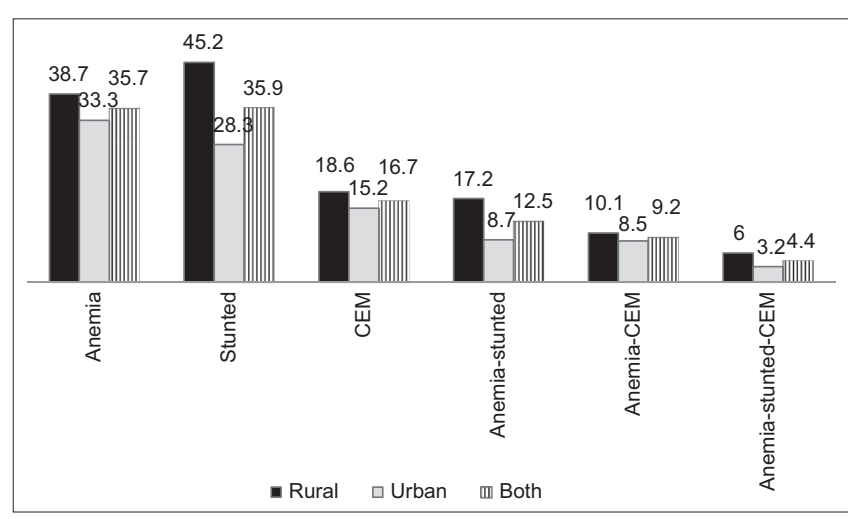

Figure 1: Type of malnutrition among pregnant women

malnutrition issue among pregnant women in this study is anemia and stunted. Anemia was obtained in $35.7 \%$ of pregnant women, stunted in $35.9 \%$, and $16.7 \%$ CEM pregnant women. Anemia and stunted almost $12.5 \%$ and anemia-CEM, nearly $10 \%$ of pregnant. However, almost all undernutrition types higher prevalence in rural areas than in urban areas.

This study also revealed that pregnant women have not only a single malnutrition problem, but also a combination of undernutrition problems such as CEM and stunting. At least double undernutrition defined when pregnant women have anemia and the other undernutrition; anemia-stunting, anemia-CEM or in the triple undernutrition problems, and anemia-stunted - CEM. Overall, nearly $17.3 \%$ of pregnant women have double undernutrition combined with anemia issues, almost similar to single malnutrition anemia in $18.4 \%$, but in rural area the results shows the most of pregnant woment have double under nutrition at least in two problem (Figure 2).

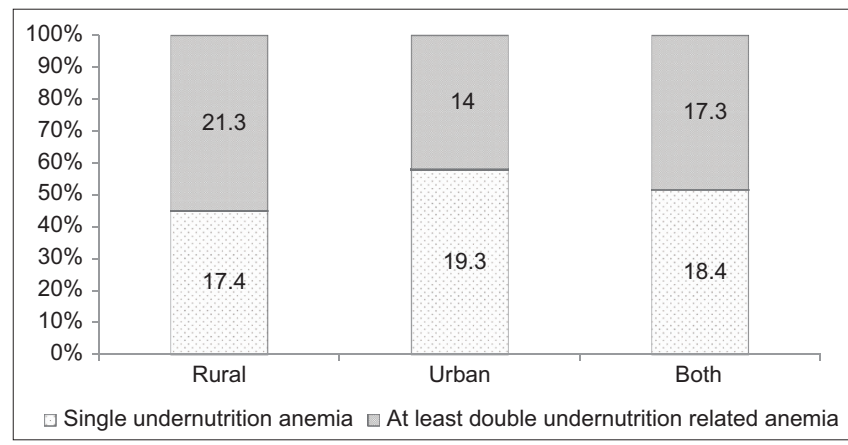

Figure 2: Double undernutrition combined with anemia in pregnant women

Chronic energy malnutrition was previously identified as a risk factor for anemia in pregnant women (Table 2). Table 2 compares the risk of anemia in pregnant women with CEM to pregnant women with another nutritional problem. Furthermore, women with CEM and stunting who live in rural areas are more likely to develop anemia than pregnant women who live in urban areas. 
Table 2: Risk of undernutrition to anemia in pregnant women

\begin{tabular}{|c|c|c|c|}
\hline \multirow[t]{3}{*}{ Undernutrition status } & \multicolumn{3}{|l|}{ Anemia } \\
\hline & Rural & Urban & Both \\
\hline & $\mathrm{n}(\%)$ & $\mathrm{n}(\%)$ & $\mathrm{n}(\%)$ \\
\hline \multicolumn{4}{|l|}{ Stunted } \\
\hline Yes & $42(40.0)$ & $19(29.7)$ & $61(36.1)$ \\
\hline No & $50(37.3)$ & 61 (33.7) & $111(35.2)$ \\
\hline AOR $(95 \% \mathrm{Cl})^{* 1}$ & $1.06(1.15-4.32)$ & $0.77(0.41-1.45)$ & $0.93(0.62-1.39)$ \\
\hline \multicolumn{4}{|l|}{ CEM } \\
\hline Yes & $24(54.5)$ & $18(48.6)$ & $62(51.9)$ \\
\hline No & $68(34.9)$ & $62(29.8)$ & $130(32.3)$ \\
\hline AOR $(95 \% \mathrm{Cl})^{\star 1}$ & $2.23(1.14-4.33)$ & $2.29(1.12-4.69)$ & $2.25(1.38-3.66)$ \\
\hline \multicolumn{4}{|l|}{ Stunted-CEM } \\
\hline Yes & $14(60.9)$ & $5(38.5)$ & $19(52.8)$ \\
\hline No & $78(36.1)$ & $75(32.3)$ & $153(34.2)$ \\
\hline AOR $(95 \% \mathrm{Cl})^{* 1}$ & $2.75(1.14-6.65)$ & $1.19(0.37-3.84)$ & $2.15(1.09-4.27)$ \\
\hline
\end{tabular}

\section{Discussion}

Anemia remains a significant public health issue during pregnancy, and the major cause is iron deficiency anemia. According to the study's primary finding, more than one-third of pregnant women suffer from anemia, and nearly half of pregnant women who suffer from anemia also have another malnutrition problem in both areas. In addition, the risk of anemia is increased in pregnant women who are also currently facing chronic malnutrition. CEM and stunting are three times more likely to developing anemia in pregnant women living in rural areas.

A previous research in western Ethiopia indicates the main cause of anemia, including low socioeconomic status, a low daily dietary diversity, irregular iron tablet supplementation, and a MUAC $<23 \mathrm{~cm}$ that predicted malnutrition, bleeding, and helminth infection[24]. Anemia during pregnancy also related to parasitic infection, mother's age, rural residence, food taboos, a history of heavy bleeding before pregnancy, and drinking tea or coffee immediately after a meal [25], [26], [27]. In addition, there are a link between anemia and macronutrient deficiency [28].

According to this study, nearly $36 \%$ of pregnant women had anemia. This pattern similar to another developing country. The prevalent also almost similar in low and middle countries that anemia occurs in one of the two pregnant women [29]. A previous research in India found that anemia affects nearly half of pregnant women, with $37.1 \%$ having mild anemia, $9.1 \%$ having moderate anemia, and $2.9 \%$ having severe anemia [30]. While, data from 2019 show that the lowest prevalence of anemia in pregnant women in development country, almost $19 \%$, which was demonstrated in America regions. Moreover, the lowest prevalence was shown in the United States (11.5\%) and Singapore for South East Asia, at $17.5 \%$ [2].

The study reveals that almost one-five of pregnant women have not only single anemia as a single malnutrition problem, but they also have another type of undernutrition, such as CEM and stunting. At least two types of malnutrition (nearly 18\%) occur concurrently in pregnant women with anemia according to this study. This results support to previous study in Ghana that showed a double burden of malnutrition among women with anemia, prevalence anemia and underweight in 13\%; anemia and overweight in nearly $57 \%$ [31]. This study supported that malnutrition can be obtained simultaneously. According to this study, pregnant women have twice the amount of anemia caused by undernutrition. The study found that chronic energy malnutrition among pregnant women has a risk of anemia higher than other nutritional problems in rural and urban areas. The previous studies also show similar results in an association between CEM and Anemia in pregnant women with almost similar risk to this study (AOR 2.18) [32].

Physiological changes during pregnancy increase nutrient demand, including macronutrients and micronutrients. An adequate intake is critical to ensuring a healthy pregnancy and reducing the negative effects of fetal growth [33], [34]. Macronutrients such as carbohydrates, proteins, and fats are used in pregnant women to provide adequate calories. Meanwhile, protein is required for tissue growth and development, including brain development and micronutrients. Protein is required for a baby's blood supply [35], [36]. Furthermore, iron combines with potassium, sodium, and water to increase blood flow in mother and the baby [37].

A lack of macronutrients during pregnancy causes a chronic energy deficiency, which can lead to a deficiency of micronutrients. The optimal metabolism of the body's micronutrients needed adequate macronutrients. A sufficient intake of protein has also contributed to the absorption and metabolism of micronutrients [32]. In the biological process, hemoglobin was synthesized by sufficient energy and protein [32], [38]. Otherwise, CEM is a chronic energy deficiency associated with the maximum vitamins and minerals of iron, iodine and other absorption. Similar findings have been found in previous studies of many micronutrient deficiencies worldwide [4]. Whilst, hemoglobin is an oxygen-binding protein that transports oxygen to the tissues from the lungs [38]. If the levels of hemoglobin are lower than normal, anemia of iron deficit is indicated. In addition, an effective method of preventing anemia in pregnant women is iron supplementation [39]. Adequate intake of iron during pregnancy by iron supplementation will reduce the risk of maternal mortality because of the complications of pregnancy [40].

This study shows that chronic energy malnutrition and stunting combine to increase the risk of anemia in rural areas. Otherwise, chronic malnutrition also was predicted by a mother's body height of $<150.1 \mathrm{~cm}$. By combining this indicator, rural areas are at greater risk of anemia than urban areas. Rural and urban disparities predict anemia at different risks due to nutrition history and sociodemography characteristics. It is also linked to rural and urban 
health behavior with the consumption of iron tablets. National basic health research conducted in 2018 has demonstrated a low prevalence of regular iron supplementation. The coverage of iron tablets for consumption greater than 90 varies from rural to urban areas. In rural areas, iron tablets are consumed at a lower rate than in urban areas $(20.6 \%$ vs. $26.5 \%)$, respectively [17]. There are many reasons for some pregnant women not taking iron tablets, such as taste, nausea and side effects [17]. In general, plagues of iron supplementation programs are irregular iron tablet consumption due to side effects [39].

According to this study, women with chronic energy malnutrition should ensure how much iron tablet supplementation they get and consume. Otherwise, pregnant women must also consume sufficient energy and protein by daily intake. Some complementary foods are also needed to boost adequate macronutrient requirements. In other words, adequate macro nutrition intake among pregnant women with CEM also is an important strategy for preventing anemia, besides iron tablets supplementations. The study's limitations are that it does not recognize pregnant women's dietary patterns and respondents' socioeconomic status information.

\section{Conclusion}

Anemia is a major cause of malnutrition among pregnant women in both rural and urban areas. Anemia is often associated with other forms of undernutrition, such as stunting and CEM. Pregnant women with CEM are at a higher risk of anemia in both areas. However, pregnant women with stunting and CEM are at the highest risk of anemia in rural areas. The significance of this study is to inform about double undernutrition issues related to anemia; in addition, an integrated control program combating malnutrition is required to prevent anemia in pregnant women.

\section{References}

1. World Health Organization. Anaemia. Geneva: World Health Organization; 2021. Available from: https://www.who.int/health-topics/anaemia\#tab=tab_1. [Last accessed on 2021 Jan 15]

2. World Health Organization. Prevalence of Anaemia in Pregnant Women Estimates by WHO Region. Geneva: World Health Organization; 2019. Available from: https://apps.who.int/gho/ data/view.main.anaemiawomenpwreg [Last accessed on 2021 Sep 02].

3. Figueredo AC, Goes-Filho IS, Silva RB, Pereira PP, Da Mata FA, Lyrio $A O$, et al. Maternal anemia and low birth weight: A systematic review and meta-analysis. Nutrients. 2018;10(5):601. http://doi.org/10.3390/nu10050601

PMid:29757207

4. Dickinson N, Macpherson G, Hursthouse AS, Atkinson J. Micronutrient deficiencies in maternity and child health: A review of environmental and social context and implications for Malawi. Environ Geochem Health. 2009;31(2):253-72.

PMid:18953657

5. Beckmann C, Ling F, Barzansky B, Herbert W, Laube D, Smith R. Embryology and anatomy. In: Obstetrics and gynecology. $6^{\text {th }}$ ed. Philadelphia, PA: Wolters Kluwer Health Liipincott Williams and Wilkins; 2010. p. 29-41.

6. Gardosi J. Normal fetal growth. In: Edmonds DK, editor. Obstetrics dan Gynaecology. $7^{\text {th }}$ ed. London, UK: Blackwell Publishing; 2007. p. 318-26.

7. Marangoni F, Cetin I, Verduci E, Canzone G, Giovannini M, Scollo $\mathrm{P}$, et al. Maternal diet and nutrient requirements in pregnancy and breastfeeding. An Italian consensus document. Nutrient. 2016;8(10):629. http://doi.org/10.3390/nu8100629 PMid:27754423

8. Williamson CS. Nutrition in Pregnancy. London, UK: British Nutrition Foundation; 2006.

9. Nguyen HA. Undernutrition during Pregnancy. Available from: http://www.intechopen.com. [Last accessed on 2021 Mar 03]

10. Papathakis PC, Singh LN, Manary MJ. Molecular and Cellular endocrinology how maternal malnutrition affects linear growth and development in the offspring. Mol Cell Endocrinol. 2016;2016:24. http://dx.doi.org/10.1016/j.mce.2016.01.024

11. Martorell R, Zongrone A. Intergenerational influences on child growth and undernutrition. Paediatr Perinat Epidemiol. 2012;26(Suppl 1):302-14. http://doi. org/10.1111/j.1365-3016.2012.01298.x PMid:22742617

12. Yang Z, Huffman SL. Nutrition in pregnancy and early childhood and associations with obesity in developing countries. Matern Child Nutr. 2013;9(Suppl 1):105-19. http://doi.org/10.1111/mcn.12010 PMid:23167588

13. Victoria C, Adair L, Fall C, Hallal P, Martorell R, Richter L, et al. Maternal and child undernutrition 2: Maternal and child. Lancet. 2008;371(9609):340-57. http://doi.org/10.1016/ S0140-6736(07)61692-4 PMid:18206223

14. Guelinckx I, Devlieger R, Beckers K, Vansant G. Maternal obesity: Pregnancy complications, gestational weight gain and nutrition. Obes Rev. 2008;9:140-50.

15. Onis M De, Branca F, de Onis M, Branca F. Childhood stunting: Aglobal perspective. Matern Child Nutr. 2016;12(Suppl 1):12-26. http://doi.org/10.1111/mcn.12231 PMid:27187907

16. Health Research and Development Agency. Basic Health Research 2013. National Report; 2013. p. 1-384.

17. National Institute Health Research. National Basic Health Research Survey Report (Riskesdas 2018). Jakarta, Indonesia: LBP Balitbangkes; 2019.

18. Ramachandran P. Double Burden of Malnutrition in Developing Countries. The Double Burden of Malnutrition in India; 2020.

19. World Health Organization. World Health Assembly Global Nutrition Targets 2025. Stunting Policy Brief. Geneva: World Health Organizationl; 2015.

20. World Health Organization. The Double Burden of Mal Nutrition. Policy Brief. Vol. 17. Geneva: World Health Organization; 2006.

21. Levy PS, Lemeshow S. In: Groves RM, Kalton G, Rao JN, Schwarz CS, editors. Sampling of Populations, Methods and Applications. $4^{\text {th }}$ ed. Mexico: A John Wiley and Sons, Inc., 
Publication; 2008.

22. Tang AM, Chung M, Dong K, Terrin N, Edmonds A, Assefa N, et al. Determining a global mid-upper arm circumference cutoff to assess malnutrition in pregnant women. Public Health Nutr. 2020;23(17):3104-13. http://doi.org/10.1017/ S1368980020000397

PMid:32799964

23. Ververs MT, Antierens A, Sackl A, Staderini VC. Which anthropometric indicators identify a pregnant woman as acutely malnourished and predict adverse birth outcomes in the humanitarian context? PLoS Curr. 2013;7:5. http://doi.org/10.1371/currents. dis.54a8b618c1bc031ea140e3f2934599c8 PMid:23787989

24. Tulu BD, Atomssa EM, Mihiretie H, Mengist HM. Determinants of anemia among pregnant women attending antenatal care in Horo Guduru Wollega Zone, West Ethiopia: Unmatched casecontrol study. PLoS One. 2019;14(10):e0224514. http://doi. org/10.1371/journal.pone.0224514

PMid:31671128

25. Teshome MS, Meskel DH, Wondafrash B. Determinants of anemia among pregnant women attending antenatal care clinic at public health facilities in Kacha Birra District, Southern. J Multidicip Healthc. 2020;13:1007-15. http://doi.org/10.2147/ JMDH.S259882

PMid:33061406

26. Weldekidan F, Kote M, Girma M, Boti N, Gultie T. Determinants of anemia among pregnant women attending antenatal clinic in public health facilities at durame town: Unmatched case control study. Anemia. 2018;2018:8938307. https://doi. org/10.1155/2018/8938307

27. Kassa GM, Muche AA, Berhe AK, Fekadu GA. Prevalence and determinants of anemia among pregnant women in Ethiopia: A systematic review and meta-analysis. 2017;17:17. http://doi. org/10.1186/s12878-017-0090-Z

PMid:29075500

28. Ugwuja El, Ogbonnaya LU, Obuna AJ, Awelegbe F, Uro-chukwu H. Anaemia in relation to Body Mass Index (BMI) and socio- demographic characteristics in adult nigerians in Ebonyi state. J Clin Diagn Res. 2015;9(1):LC04-7. http://doi. org/10.7860/JCDR/2015/9811.5485 PMid:25738011

29. Darnton-hill I, Mkparu UC. Micronutrients in pregnancy in low and middle-income countries. Nutrients. 2015;7(3):1744-68. http://doi.org/10.3390/nu7031744 PMid:25763532

30. Lilare RR, Sahoo DP. Prevalence of anaemia and its epidemiological correlates among women of reproductive age group in an urban slum of Mumbai prevalence of anaemia and its epidemiological correlates among women of reproductive age group in an urban slum of Mumbai. Int $\mathrm{J}$ Community Med Public Health. 2018;4(8):3-9. http://dx.doi.org/10.18203/23946040.ijcmph20173333

31. Boatemaa S, Owusu L, Kushitor MK. The prevalence and correlates of the double burden of malnutrition among women in Ghana. PLoS One. 2020;15(12):e0244362. http://doi. org/10.1371/journal.pone.0244362

PMid:33370352

32. Mulyantoro DK, Kusrini I. Protein Energy Deficiency Increases the Risk of Anemia in Pregnant Women Protein Energy Deficiency Increases the Risk of Anemia in Pregnant Women; 2021. p. 8-13.

33. Wilson RL, Gummow JA, Mcaninch D, Bianco-miotto T, Roberts CT. Vitamin and mineral supplementation in pregnancy: Evidence to practice. Pharm Pract Res. 2018;48(2):186-92. https://doi.org/10.1002/jppr.1438

34. Bailey L. The epidemiology of global micronutrient deficiencies the epidemiology of global micronutrient. Ann Nutr Metab. 2015;66(Suppl 2):22-33. http://doi.org/10.1159/000371618 PMid:26045325

35. Berti C, Decsi T, Dykes F, Hermoso M, Koletzko B, Massari $M$, et al. Critical issues in setting micronutrient recommendations for pregnant women: An insight. Matern Child Nutr. 2010;6(S2):5-22. https://doi. org/10.1111/j.1740-8709.2010.00269.x

36. Vir SC, Seshadri S. Nutritional anemia during pregnancy, early childhood and adolescence: The critical development periods. In: Public Health in Developing Countries. Sawston, Cambridge: Woodhead Publishing Limited; 2011. p. 674-712.

37. Morse NL. Benefits of docosahexaenoic acid, folic acid, vitamin $\mathrm{d}$ and iodine on foetal and infant brain development and function following maternal supplementation during pregnancy and lactation. Nutrient. 2012;4(7):799-840. http://doi.org/10.3390/ nu4070799

PMid:22852064

38. Farid $Y$, Bowman NS, Lecat P. Biochemistry, Hemoglobin Synthesis. Treasure Island, FL: StatPearls; 2021.

39. Lopez A, Cacoub P, Macdougall IC, Peyrin-Biroulet L. Iron deficiency anaemia. Lancet. 2016;387(10021):907-16. http:// doi.org/10.1016/S0140-6736(15)60865-0

PMid:26314490

40. Agrawal S, Fledderjohann J, Vellakkal S, Stuckler D. Adequately diversified dietary intake and iron and folic acid supplementation during pregnancy is associated with reduced occurrence of symptoms suggestive of pre- eclampsia or eclampsia in Indian women. PLoS One. 2015;2015:e0119120. http://doi. org/10.1371/journal.pone. 0119120

PMid:25785774 